\title{
MECHANISMS FOR THE DEVELOPMENT OF ECOTOURISM IN UZBEKISTAN
}

\author{
Aziza Mirzaeva
}

Master's Degree Student Jizzakh State Pedagogical Institute Tashkent, Uzbekistan

\section{ABSTRACT}

Mechanisms for the development of ecotourism have been developed with a comprehensive study of natural and tourist sites in Uzbekistan.

KEYWORDS: - Ecotourism, recreation zone, recreation, treatment zones, tourist routes, exotic landscapes of foreign tourists, recreational resources, tourist route, from plain to mountain in Uzbekistan.

\section{INTRODUCTION}

To date, in Uzbekistan, the mountains in the Tashkent region are relatively well developed in terms of mountain tourism. There are 7 recreational zones, 4 of which are fully formed recreation and treatment zones. Development is not high, although there are many recreational and mountain tourism facilities in the mountainous areas of other provinces. There are opportunities for further development of international mountain tourism in the mountainous areas of Jizzakh, Samarkand, Kashkadarya, Surkhandarya regions and in the mountains around the Fergana Valley, where most of the area is occupied by mountains, in recreational areas and with the effective use of tourist facilities.

The main results and findings

For the first time in the effective development of international mountain tourism in the mountainous region of Uzbekistan, the effective use of existing opportunities (ie technical facilities - hotels, camping, restaurants, etc.), ie the effective use of recreational resources for the natural, historical and cultural heritage of our country. We recommend a tourist route system. It is no secret that currently it is very difficult to build hotels for international tourists in the mountainous regions of Uzbekistan. In the cities of the foothills of Uzbekistan (Shahrisabz, Urgut, Samarkand, Jizzakh and Chirchik), there are enough hotels for tourists. There are also roads from some mountainous cities to mountainous areas (e.g., from Zaamin to the Turkestan Mountains, from Gazalkent to the Chimgan Mountains). At the same time, the tourist routes will be directed from the plains to historical monuments, oases, artificial hydraulic structures, etc. - to the mountains (exotic landscapes).

The main part. Historically, there have been many migrations of the population from plain to mountain and from mountain to plain. We can see that cattle breeders, farmers and hunters moved from the plains to the mountains or from the mountains to the plains depending on the seasons and lived a seasonal life. 
CURRENT RESEARCH JOURNAL OF HISTORY 2(6): 34-38, June 2021

DOI: https://doi.org/10.37547/history-crjh-02-06-08

ISSN 2767-472X

(C)2021 Master Journals

\section{Crossref dof 11 Google}

Accepted 14 $4^{\text {th }}$ June, 2021 \& Published 19thJune, 2021

The mountain ranges surrounding the Zarafshan valley also allow for the development of various forms of tourism. The proximity of Samarkand, Urgut, Kattakurgan and other cities to the mountainous areas allows foreign tourists to relax and unwind in the mountains of Zarafshan, as well as to see the historical monuments on the plains. The Zarafshan valley is characterized by a variety of natural conditions. The relief of the Zarafshan mountains makes it possible to organize various tourist hikes, especially in the field of mountaineering.

There are more than 30 caves and thousands of karsts in the Zarafshan mountains, which allow the development of underground tourism. The Zarafshan mountains are composed of lightmelting, karst-forming Devonian limestones. Therefore, these mountains are distinguished by the abundance of ancient karst caves.

There is a world-famous Amankoton cave, especially $40 \mathrm{~km}$ south of Samarkand. Omonkoton cave is located at an altitude of 1220 $m$ along the Samarkand-Kitab road. The cave was opened in 1947 by D.N. Lev, an associate professor at SamSU, and it was discovered that ancient people lived in the Ustya period.

The best route for foreign tourists is SamarkandAmankoton cave. Outside the cave, foreign tourists see mixed forests created by human hands on the slopes of the mountain a century and a half ago around the Amonkoton River. Another route in the region is the Kyrgyz plateau with a unique exotic landscape, located at an altitude of 2200-2300 $\mathrm{m}$ at the watershed of the Zarafshan ridge, $50 \mathrm{~km}$ south of Samarkand. It has a terrific lunar "landscape" and is composed of Devonian limestone from the plateau, which is an example of the extensive, intensive and classical development of karst processes in Central Asia. There are more than 3,000 karst tunnels, 64 cavities, as well as 5 horizontal caves, 56 wells and mines. The deepest mine is $1080 \mathrm{~m}$ deep and has a large catchment lake. This karst lake supplies water to Urgut district of Samarkand region and Kitob district of Kashkadarya region. This Kiev karst cave is the deepest natural cave on the Asian continent. On the surface, it ranks 3rd among the deepest natural caves.

Tourists walk along the route SamarkandKamongoron (Urgut district) to see the Kiev karst cave (there is a bus route to the village of Kamongoron). From the village of Kamongoron you can go to the Kiev karst cave on horseback or by helicopter. This route is not expensive for foreign tourists.

Above, we have expressed some ideas about the routes of vertical movement from the plain to the mountain in the example of the Zarafshan valley. As the plateau rises from the plains to the mountains, the number of tourist attractions also increases. Taking into account the characteristics of vertical landscape zones also plays an important role in the development of mountain tourism.

The need to build health resorts in the mountains is associated with the deterioration of the ecological situation in the plains of the country, environmental pollution in major cities. In summer, the heat on the plains is exacerbated by the prevailing hot weather and, accordingly, limited opportunities for recreation. As a result, the population's holiday season is now spontaneously increasing in the mountains. The chaotic nature of the holiday does a lot of damage to the natural environment.

Therefore, it is necessary to create recreational bases that are of international importance and meet environmental requirements, as opposed to the spontaneous use of recreational resources.

It should be noted that the mountain resorts of Sante $\mathrm{Fe}$ in the United States and Lordjini in India, located in conditions similar to the 
mountainous conditions in Uzbekistan, are also famous all over the world. In terms of climatic conditions, topography and unique complex natural conditions, the Supa Plateau in the Turkestan ridge is more convenient than many mountain sports centers in the world. Only here, a lot of creative work needs to be done to develop international mountain tourism.

Along with the development of recreational opportunities in the mountainous regions of Uzbekistan and the development of mountain tourism, it is important to study the scientific and theoretical aspects of tourism. In the scientifictheoretical assessment of tourism, it is necessary to determine the stability of landscape recreational resources to anthropogenic load and the recreational size of the area.

It should be noted that in the future, along with the development of mountain tourism in Uzbekistan, geographers will have a new task to protect the landscape, that is, to protect the landscape for tourists - to maintain the beauty, attractiveness and productivity of landscapes.

As a result of many years of research, 4 natural complexes have been identified in the Zominsuv basin of the Turkestan ridge according to the change of landscapes depending on the altitude zones. Natural complexes of each region were identified according to their tourist significance and its tourist potential was assessed.

\section{Altitude zones of the Zominsuv basin and}

\begin{tabular}{|c|l|l|l|}
\hline № & $\begin{array}{l}\text { Altitude landscape } \\
\text { zones }\end{array}$ & \multicolumn{1}{|c|}{$\begin{array}{c}\text { Natural complexes of tourist } \\
\text { importance }\end{array}$} & \multicolumn{1}{c|}{ Tourist opportunities } \\
\hline I & $\begin{array}{l}\text { Pre-mountain plain and } \\
\text { Zominsuv spread (450- } \\
850 \mathrm{~m} \text { ) 1. The upper } \\
\text { part of the spread }\end{array}$ & $\begin{array}{l}\text { 1. The upper part of the spread } \\
\text { 2. The border of the spread is the } \\
\text { city of Zaamin and its recreation } \\
\text { areas }\end{array}$ & $\begin{array}{l}\text { The border of the spread is } \\
\text { the city of Zaamin and its } \\
\text { recreation areas } \\
\text { Agro landscapes }\end{array}$ \\
\hline II & $\begin{array}{l}\text { Low-mountain dry- } \\
\text { subtropical zone with } \\
\text { hilly ridges (900-1800 } \\
\text { m) }\end{array}$ & $\begin{array}{l}\text { 3. River valley, terrace } \\
\text { landscapes } \\
\text { 4. Inter-river watershed Short- } \\
\text { term rest in summer }\end{array}$ & $\begin{array}{l}\text { Inter-river watershed Short- } \\
\text { term rest in summer } \\
\text { Excursion in the spring }\end{array}$ \\
\hline III & $\begin{array}{l}\text { Medium high mountain } \\
\text { forest zone with steep } \\
\text { slopes (1800-2000, } \\
\text { 2600-2800 m) }\end{array}$ & $\begin{array}{l}\text { 5. Kizilmozor complex } \\
\text { consisting of Pomogen-Neocene } \\
\text { lines } \\
\text { 6. Wavy high mountain plateau } \\
\text { platform complex } \\
\text { 7. Karst incident curves typical } \\
\text { of rare tropical zones } \\
\text { 8. Excursion to the rock } \\
\text { sculptures "Forty-girls" of the }\end{array}$ & $\begin{array}{l}\text { Excursion to the rock } \\
\text { sculptures "Forty girls" } \\
\text { Travel to the gorge where 4 } \\
\text { rivers (Sharillak, Kizilsuv, } \\
\text { Kashkasuv and Kolsay) are } \\
\text { connected, which has tourism } \\
\text { opportunities of world } \\
\text { importance. }\end{array}$ \\
\hline
\end{tabular}




\begin{tabular}{|c|c|c|c|c|}
\hline & & & $\begin{array}{l}\text { Chortangi landscape } \\
\text { Travel to the gorge where } 4 \\
\text { rivers (Sharillak, Kizilsuv, } \\
\text { Kashkasuv and Kolsay) join the } \\
\text { world-famous tourism } \\
\text { opportunities. }\end{array}$ & \\
\hline IV & $\begin{array}{l}\text { High } \\
\text { watershed } \\
\text { zone }\end{array}$ & $\begin{array}{l}\text { mountain } \\
\text { subalpine }\end{array}$ & $\begin{array}{l}\text { 9. Complex of Shahristan } \\
\text { and Goralash passes } \\
\text { 10. Large water intake } \\
\text { complex } \\
11 . \text { Giant steep cliffs } \\
\text { (called "Meeting", "Wait" and } \\
\text { others) In the summer you can } \\
\text { ride in the car to the ancient } \\
\text { denudation faces. }\end{array}$ & $\begin{array}{l}\text { In the summer, you can ride } \\
\text { on the old denudation faces in } \\
\text { the car. } \\
\text { Short excursions in summer. } \\
\text { Excursions to the rocks called } \\
\text { "Wait" and "Meeting" are } \\
\text { available }\end{array}$ \\
\hline
\end{tabular}

When describing the landscapes of the Zaamin basin as natural complexes of altitude zones, relief, geological and geomorphological components are taken as a basis. Components of these natural complexes, such as climate, hydrological and biological, are very suitable for the development of mountain tourism.

\section{Conclusion}

Along with the large-scale development of international mountain tourism in Uzbekistan, there are some factors that hinder it. Factors hindering the development of international mountain tourism in the mountains are conditionally divided into 2 . These are internal and external factors.

Internal factors that hinder the establishment of recreation areas in the mountains include problems such as frequent floods in early spring and early summer, road construction, and power supply. Large floods are observed in the mountains when snow melts and rains coincide.
The relief features of the mountains are very inconvenient for road construction. This, in turn, will cause great damage to nature if large-scale road construction works are carried out in the mountains. Laying power lines to high mountainous areas is expensive.

External factors that hinder the organization of recreation areas in the mountains are the fact that many mountains in Uzbekistan are located close to the state borders with neighboring republics. Therefore, the establishment of large recreation areas in these areas is not in line with the state strategy.

According to the results of the research, it is necessary to organize modern tents (pastures), rather than the construction of large buildings, which have become a traditional method of organizing recreation areas. Holiday tents can be set up seasonally, even in the vicinity of the state borders of the mountains. Since holiday tents do not require a large area, it will be possible to place them away from flood paths. Also, if 
alternative energy (solar, wind and bioenergy) is used efficiently to supply tents with electricity, large sums of money will not be required for the transmission of power lines.

When building highways in the mountains, the slope should not exceed 12-150. In areas where the slope is high in the mountains, it is necessary to build cable cars. Some trails can be traversed by local animals such as donkeys, camels. Through such movements, the mountain nature is fully enjoyed. It also prevents mountain diseases that occur during rapid ascent from the plains to the mountains. Most importantly, such recreation in the bosom of nature does not adversely affect the environment and, moreover, fully complies with the requirements of the "Environmental Program" developed by the UN.

\section{REFERENCES}

1. Alibekov L, Alibekova S, Hazarov I, Gudalov M. About some regularities of geosystems degradation in Central Asia. Tatranka Javorina, Slovakia, 2012, Vol 21, № - $1,42-44 \mathrm{p}$

2. Gudalov M. Foundation of Aydar-Arnasay lakes system and their effects on the environmental landscape. Nature and Science.Volume 17, Number 11 November 25, 2019 USA New York.

3. Gudalov M., Zikirov B. Metnods of studying the landscapes around the Aydar-Arnasay lake system. International engineering journal for research \& development. Vol - 5, Issue - 7, 2020 India.

4. Gudalov M., Zikirov B., Imamova D. Predicting changes in landscares around the Aydar-Arnasay lake system. Accerted in the journal The American of Engineering and Technology. Volume -
02, Issue - 10, October 2020.

5. Gudalov M., Gozieva M. Ways to develor modern ecoturism in the Zamin basin. International engineering journal for research \& development. Vol - 5, Issue 7, 2020 India.

6. Sharipov Sh, Gudalov M, Shomurodova Sh. Geolologic situation in the AydarArnasay colony and its atropny. Journal of Critical Reviews. Volume 7, Issue 3, 2020 Maleziya Kuala-Lumpur.

7. Sharipov Sh, Shomurodova Sh, Gudalov $M$. The use of the mountain kars in the tourism sphere in cort and recreation zone of Chimgan-Charvak. Journal of Critical Reviews. Volume 7, Issue 3, 2020 Maleziya Kuala-Lumpur.

8. Gudalov, M., \& Gozieva, M. (2020, December). Development Of Tourism In Zaamin National Nature Park By The Cluster Method. In INTERNATIONAL SCIENTIFIC AND CURRENT RESEARCH CONFERENCES (pp. 111-114). 